Alexander, W. D., Harden, R. McG., Shimmins, J., McLarty, D., and McGill, P. (1967). Fournal of Endocrinology, 27, 1682.

Alexander, W. D., Harden, R. McG., and Shimmins, J. (1968). Lancet, 2 , 196.

Alexander, W. D., Harden, R. McG., McLarty, D., and Shimmins, J. (1969). Metabolism, 1, 58 .

Cassidy, C. E., and VanderLaan, W. P. (1960). New England fournal of Medicine, 262, 1228.

Chopra, I. J., Solomon, D. H., Johnson, D. E., Chopra, U., and Fisher, D. A. (1970). Fournal of Endocrinology, 30, 524

Hales, I., Stiel, J., Reeve, T., Heap, T., and Myhill, J. (1969). fournal of Endocrinology, 29, 998.
Harden, R. McG., Alexander, W. D., Koutras, D. A., Harrison, M. T., and Wayne, E. (1966). Fournal of Endocrinology, 26, 397.

Koutras, D. A., and Sfontouris, J. (1966). Fournal of Endocrinology, 35, 135 Morgans, M. E., Oldham, A. K., and Trotter, W. R. (1952). Fournal of Endocrinology, 8, 250.

Stanley, M. M., and Astwood, E. B. (1948). Endocrinology, 42, 107.

Werner, S. C. (1956), Fournal of Clinical Investigation, 35, 57 .

Werner, S. C., Hamilton, H., and Nemeth, M. (1952). Fournal of Endocrinology, 12, 1561.

Werner, S. C., and Spooner, M. (1955). Bulletin of the New York Academy of Sciences, 31, 137.

\title{
Urinary Sodium and Potassium Excretion in Fasting Obese Subjects
}

\section{J. RUNCIE}

\section{British Medical fournal, 1971, 2, 22-25}

\section{Summary}

Data are presented on the urinary excretion of sodium and potassium in $\mathbf{4 0}$ obese patients subjected to therapeutic starvation. Two patterns of sodium loss were observed: either a uniform low-level loss or a fluctuating loss leading in some cases to marked sodium depletion. In three patients the response was a combination of these two patterns.

\section{Introduction}

Therapeutic starvation as a significant mode of therapy for the obese patient dates from the observations of Bloom (1959), which were extended by Duncan et al. (1962), Drenick et al. (1964), and Thompson et al. (1966) and which established the validity of this form of treatment. Runcie and Thomson (1970) reviewed the hazards of therapeutic starvation and

University of Glasgow, Stobhill Hospital, Glasgow N.1

J. RUNCIE, M.B., M.R.C.P.GLASG., Lecturer in Materia Medica drew attention to a hitherto unrecognized danger, the spontaneous development of a renal leak of electrolytes (sodium and potassium), leading to hyponatraemic shock.

With acceptance of the principle of therapeutic starvation interest has become increasingly focused on the mechanisms and adaptive responses necessary to enable man to survive prolonged deprivation of food. Considerable advances have been made in some fields, such as the description by Cahill and his co-workers (Cahill et al., 1966; Felig et al., 1969; Owen et al., 1969) of many essential changes in protein metabolism in fasting.

The purpose of this communication is to present data on the urinary excretion of sodium and potassium in 40 obese patients who had undergone varying periods of therapeutic starvation and to consider the nature of this response and its role in the integrated, adaptive, renal response to starving.

\section{Methods}

The management of obese patients admitted to the wards of the University Department of Materia Medica for therapeutic starvation has been described previously (Thomson et al., 1966). The urine of all patients is collected continuously in

TABLE I-Urinary Sodium ( $m E q / 24 \mathrm{hr})$

\begin{tabular}{|c|c|c|c|c|c|c|c|c|c|c|c|c|c|c|c|c|c|c|c|c|c|c|c|}
\hline \multirow{2}{*}{\multicolumn{2}{|c|}{$\begin{array}{l}\text { Case } \\
\text { No. }\end{array}$}} & \multirow{2}{*}{$\begin{array}{c}\text { Age } \\
\text { (years) }\end{array}$} & \multirow{2}{*}{ Sex } & \multicolumn{20}{|c|}{ Fast (Day) } \\
\hline & & & & 1 & 2 & 3 & 4 & 5 & 6 & 7 & 8 & 9 & 10 & 11 & 12 & 13 & 14 & 15 & 16 & 17 & 18 & 19 & 20 \\
\hline $\begin{array}{r}1 \\
2 \\
3 \\
4 \\
5 \\
6 \\
7 \\
8 \\
9 \\
10\end{array}$ & $\begin{array}{l}\ldots \\
\because \\
\cdots \\
\cdots \\
\cdots \\
\cdots\end{array}$ & $\begin{array}{l}14 \\
16 \\
28 \\
29 \\
31 \\
35 \\
48 \\
47 \\
52 \\
57\end{array}$ & $\begin{array}{l}\text { M. } \\
\text { F. } \\
\text { M. } \\
\text { F. } \\
\text { F. } \\
\text { F. } \\
\text { F. } \\
\text { M. } \\
\text { F. } \\
\text { F. }\end{array}$ & $\begin{array}{r}60 \\
109 \\
151 \\
93 \\
142 \\
43 \\
114 \\
174 \\
120 \\
141\end{array}$ & $\begin{array}{r}62 \\
98 \\
118 \\
65 \\
74 \\
55 \\
114 \\
165 \\
106 \\
52\end{array}$ & $\begin{array}{r}95 \\
90 \\
106 \\
42 \\
51 \\
70 \\
90 \\
102 \\
46\end{array}$ & $\begin{array}{r}61 \\
122 \\
94 \\
35 \\
73 \\
74 \\
43 \\
127 \\
68 \\
42\end{array}$ & $\begin{array}{r}25 \\
110 \\
63 \\
28 \\
47 \\
85 \\
16 \\
38 \\
48 \\
52\end{array}$ & $\begin{array}{r}11 \\
45 \\
59 \\
17 \\
27 \\
104 \\
32 \\
120 \\
40 \\
26\end{array}$ & $\begin{array}{r}1 \\
13 \\
15 \\
12 \\
11 \\
95 \\
32 \\
29 \\
75\end{array}$ & $\begin{array}{r}0 \\
0 \\
13 \\
40 \\
4 \\
77 \\
78 \\
18 \\
6\end{array}$ & $\begin{array}{r}2 \\
3 \\
14 \\
47 \\
4 \\
57 \\
94 \\
6 \\
21 \\
40\end{array}$ & $\begin{array}{r}1 \\
8 \\
11 \\
1 \\
31 \\
40 \\
13 \\
17 \\
51\end{array}$ & $\begin{array}{r}2 \\
3 \\
9 \\
2 \\
16 \\
36 \\
25 \\
9 \\
68\end{array}$ & $\begin{array}{r}3 \\
1 \\
15 \\
2 \\
7 \\
20 \\
40 \\
17 \\
101\end{array}$ & $\begin{array}{r}4 \\
0 \\
58 \\
1 \\
11 \\
29 \\
31 \\
17 \\
64\end{array}$ & $\begin{array}{r}5 \\
1 \\
14 \\
1 \\
15 \\
20 \\
30 \\
4 \\
30\end{array}$ & $\begin{array}{r}4 \\
2 \\
31 \\
44 \\
1 \\
31 \\
11 \\
30 \\
6 \\
30\end{array}$ & $\begin{array}{r}4 \\
1 \\
24 \\
32 \\
1 \\
19 \\
11 \\
31 \\
11 \\
13\end{array}$ & $\begin{array}{r}3 \\
0 \\
19 \\
31 \\
2 \\
24 \\
25 \\
35 \\
13 \\
4\end{array}$ & $\begin{array}{r}1 \\
1 \\
24 \\
36 \\
11 \\
9 \\
28 \\
21 \\
11 \\
3\end{array}$ & $\begin{array}{r}1 \\
1 \\
32 \\
32 \\
13 \\
18 \\
34 \\
14 \\
6 \\
3\end{array}$ & $\begin{array}{r}2 \\
11 \\
15 \\
32 \\
4 \\
30 \\
20 \\
13 \\
4 \\
1\end{array}$ \\
\hline
\end{tabular}

TABLE II-Urinary Sodium ( $m E q / 24 h r)$

\begin{tabular}{|c|c|c|c|c|c|c|c|c|c|c|c|c|c|c|c|c|c|c|c|c|c|c|c|}
\hline \multirow{2}{*}{$\begin{array}{l}\text { Case } \\
\text { No. }\end{array}$} & \multirow{2}{*}{$\begin{array}{c}\text { Age } \\
\text { (years) }\end{array}$} & \multirow{2}{*}{ Sex } & \multicolumn{21}{|c|}{ Fast (Day) } \\
\hline & & & 40 & 41 & 42 & 43 & 44 & 45 & 46 & 47 & 48 & 49 & 50 & 51 & 52 & 53 & 54 & 55 & 56 & 57 & 58 & 59 & 60 \\
\hline $\begin{array}{r}1 \ldots \\
2 \ldots \\
3 \ldots \\
4 \ldots \\
5 \ldots \\
6 \ldots \\
7 \ldots \\
8 \ldots \\
9 \ldots \\
10 \ldots\end{array}$ & $\begin{array}{l}14 \\
16 \\
28 \\
29 \\
31 \\
35 \\
48 \\
47 \\
52 \\
57\end{array}$ & $\begin{array}{l}\text { M. } \\
\text { F. } \\
\text { M. } \\
\text { F. } \\
\text { F. } \\
\text { F. } \\
\text { F. } \\
\text { M. } \\
\text { F. } \\
\text { F. }\end{array}$ & $\begin{array}{c}\text { Fast } \\
24 \\
5 \\
90 \\
109 \\
1 \\
37 \\
33 \\
9 \\
15\end{array}$ & $\begin{array}{r}\text { ended } \\
19 \\
6 \\
118 \\
52 \\
2 \\
60 \\
34 \\
7 \\
8\end{array}$ & $\begin{array}{c}\text { fter } 27 \\
11 \\
9 \\
106 \\
34 \\
3 \\
60 \\
50 \\
8 \\
3\end{array}$ & $\begin{array}{r}\text { days } \\
3 \\
8 \\
138 \\
4 \\
4 \\
82 \\
39 \\
8 \\
4\end{array}$ & $\begin{array}{r}8 \\
5 \\
134 \\
8 \\
11 \\
27 \\
10 \\
1\end{array}$ & $\begin{array}{r}2 \\
4 \\
31 \\
17 \\
29 \\
39 \\
9 \\
3\end{array}$ & $\begin{array}{r}11 \\
4 \\
130 \\
28 \\
37 \\
43 \\
58 \\
6 \\
17\end{array}$ & $\begin{array}{r}16 \\
6 \\
261 \\
20 \\
25 \\
16 \\
47 \\
10 \\
8\end{array}$ & $\begin{array}{r}17 \\
6 \\
142 \\
18 \\
31 \\
5 \\
46 \\
8 \\
15\end{array}$ & $\begin{array}{r}8 \\
7 \\
34 \\
22 \\
42 \\
36 \\
50 \\
7 \\
17\end{array}$ & $\begin{array}{r}13 \\
6 \\
84 \\
12 \\
41 \\
22 \\
47 \\
4 \\
42\end{array}$ & $\begin{array}{l}29 \\
24 \\
15 \\
21 \\
50 \\
68 \\
14 \\
45\end{array}$ & $\begin{array}{l}-2 \\
36 \\
11 \\
\text { Fast } \\
32 \\
91 \\
5 \\
55\end{array}$ & $\begin{array}{c}6 \\
6 \\
81 \\
14 \\
\text { ended } \\
24 \\
39 \\
10 \\
-\end{array}$ & $\begin{array}{r}3 \\
4 \\
66 \\
8 \\
11 \\
30 \\
21\end{array}$ & $\begin{array}{r}11 \\
5 \\
142 \\
13 \\
43 \\
44 \\
\frac{7}{7}\end{array}$ & $\begin{array}{r}12 \\
6 \\
52 \\
18 \\
20 \\
47 \\
7 \\
12\end{array}$ & $\begin{array}{r}17 \\
6 \\
44 \\
39 \\
48 \\
43 \\
6 \\
7\end{array}$ & $\begin{array}{r}14 \\
8 \\
44 \\
49 \\
41 \\
45 \\
11 \\
12\end{array}$ & $\begin{array}{r}16 \\
6 \\
125 \\
78 \\
28 \\
46 \\
7 \\
22\end{array}$ & $\begin{array}{r}18 \\
6 \\
45 \\
144 \\
61 \\
32 \\
7 \\
20\end{array}$ \\
\hline
\end{tabular}


TABLE III-Urinary Potassium $(m E q / 24 h r)$

\begin{tabular}{|c|c|c|c|c|c|c|c|c|c|c|c|c|c|c|c|c|c|c|c|c|c|c|}
\hline \multirow{2}{*}{$\begin{array}{l}\text { Case } \\
\text { No. }\end{array}$} & \multirow{2}{*}{$\underset{\left(\begin{array}{c}\text { Age } \\
\text { years })\end{array}\right.}{ }$} & \multirow{2}{*}{ Sex } & \multicolumn{20}{|c|}{ Fast (Day) } \\
\hline & & & 1 & 2 & 3 & 4 & 5 & 6 & 7 & 8 & 9 & 10 & 11 & 12 & 13 & 14 & 15 & 16 & 17 & 18 & 19 & 20 \\
\hline $\begin{array}{r}1 \\
2 \\
3 \\
4 \\
5 \\
6 \\
7 \\
8 \\
9 \\
10\end{array}$ & $\begin{array}{l}14 \\
16 \\
28 \\
29 \\
31 \\
35 \\
48 \\
47 \\
52 \\
57\end{array}$ & $\begin{array}{c}\text { M. } \\
\text { F. } \\
\text { M. } \\
\text { F. } \\
\text { F. } \\
\text { F. } \\
\text { F. } \\
\text { M. } \\
\text { F. }\end{array}$ & $\begin{array}{l}31 \\
39 \\
45 \\
27 \\
25 \\
24 \\
46 \\
52 \\
43 \\
39\end{array}$ & $\begin{array}{l}20 \\
28 \\
25 \\
36 \\
21 \\
27 \\
40 \\
30 \\
30 \\
20\end{array}$ & $\begin{array}{l}35 \\
21 \\
23 \\
35 \\
22 \\
26 \\
42 \\
28 \\
18\end{array}$ & $\begin{array}{l}32 \\
30 \\
32 \\
18 \\
35 \\
29 \\
37 \\
28 \\
29 \\
18\end{array}$ & $\begin{array}{r}35 \\
44 \\
36 \\
34 \\
34 \\
29 \\
26 \\
9 \\
27 \\
19\end{array}$ & $\begin{array}{l}30 \\
46 \\
38 \\
25 \\
24 \\
24 \\
27 \\
38 \\
51 \\
16\end{array}$ & $\begin{array}{l}12 \\
36 \\
21 \\
21 \\
18 \\
30 \\
38 \\
40 \\
21\end{array}$ & $\begin{array}{r}7 \\
27 \\
34 \\
18 \\
22 \\
32 \\
22 \\
35 \\
8\end{array}$ & $\begin{array}{r}16 \\
7 \\
24 \\
20 \\
23 \\
30 \\
25 \\
10 \\
27 \\
24\end{array}$ & $\begin{array}{l}10 \\
19 \\
23 \\
12 \\
28 \\
18 \\
23 \\
26 \\
20\end{array}$ & $\begin{array}{l}\overline{17} \\
23 \\
17 \\
18 \\
23 \\
24 \\
27\end{array}$ & $\begin{array}{l}31 \\
11 \\
29 \\
23 \\
18 \\
14 \\
25 \\
26 \\
43\end{array}$ & $\begin{array}{r}19 \\
9 \\
26 \\
15 \\
19 \\
18 \\
23 \\
19 \\
36\end{array}$ & $\begin{array}{l}28 \\
10 \\
23 \\
13 \\
19 \\
13 \\
24 \\
10 \\
24\end{array}$ & $\begin{array}{r}31 \\
6 \\
34 \\
20 \\
14 \\
24 \\
11 \\
24 \\
13 \\
32\end{array}$ & $\begin{array}{l}17 \\
12 \\
36 \\
20 \\
14 \\
12 \\
12 \\
23 \\
19 \\
28\end{array}$ & $\begin{array}{r}14 \\
5 \\
21 \\
20 \\
16 \\
20 \\
14 \\
25 \\
27 \\
9\end{array}$ & $\begin{array}{r}8 \\
7 \\
21 \\
17 \\
22 \\
10 \\
23 \\
20 \\
18 \\
19\end{array}$ & $\begin{array}{r}1 \\
9 \\
18 \\
16 \\
25 \\
19 \\
25 \\
26 \\
17 \\
12\end{array}$ & $\begin{array}{r}2 \\
7 \\
27 \\
16 \\
15 \\
16 \\
27 \\
20 \\
10 \\
9\end{array}$ \\
\hline
\end{tabular}

TABLE IV-Urinary Potassium ( $m E q / 24 \mathrm{hr}$ )

\begin{tabular}{|c|c|c|c|c|c|c|c|c|c|c|c|c|c|c|c|c|c|c|c|c|c|c|c|}
\hline \multirow{2}{*}{$\begin{array}{l}\text { Case } \\
\text { No. }\end{array}$} & \multirow{2}{*}{$\begin{array}{c}\text { Age } \\
\text { (years) }\end{array}$} & \multirow{2}{*}{ Sex } & \multicolumn{21}{|c|}{ Fast (Day) } \\
\hline & & & 40 & 41 & 42 & 43 & 44 & 45 & 46 & 47 & 48 & 49 & 50 & 51 & 52 & 53 & 54 & 55 & 56 & 57 & 58 & 59 & 60 \\
\hline $\begin{array}{r}1 \ldots \\
2 \ldots \\
3 \ldots \\
4 \ldots \\
5 \ldots \\
6 \ldots \\
7 \ldots \\
8 . \\
9 . \\
10 \ldots\end{array}$ & $\begin{array}{l}14 \\
16 \\
28 \\
29 \\
31 \\
35 \\
48 \\
47 \\
52 \\
57\end{array}$ & $\begin{array}{l}\text { M. } \\
\text { F. } \\
\text { M. } \\
\text { F. } \\
\text { F. } \\
\text { F. } \\
\text { F. } \\
\text { M. } \\
\text { F. } \\
\text { F. }\end{array}$ & $\begin{array}{l}\text { Fast } \\
12 \\
11 \\
20 \\
20 \\
4 \\
12 \\
22 \\
8 \\
15\end{array}$ & $\begin{array}{r}\text { rndec } \\
9 \\
11 \\
20 \\
14 \\
4 \\
14 \\
19 \\
13 \\
14\end{array}$ & $\begin{array}{c}\text { ter } 2 \\
9 \\
11 \\
19 \\
15 \\
4 \\
10 \\
35 \\
18 \\
20\end{array}$ & $\begin{array}{r}\text { days } \\
8 \\
14 \\
30 \\
8 \\
8 \\
4 \\
19 \\
7 \\
15\end{array}$ & $\begin{array}{r}8 \\
16 \\
20 \\
8 \\
8 \\
3 \\
18 \\
10\end{array}$ & $\begin{array}{r}7 \\
13 \\
25 \\
9 \\
11 \\
13 \\
9 \\
6\end{array}$ & $\begin{array}{r}10 \\
11 \\
23 \\
10 \\
11 \\
3 \\
18 \\
11 \\
14\end{array}$ & $\begin{array}{r}14 \\
10 \\
7 \\
11 \\
3 \\
17 \\
18 \\
15\end{array}$ & $\begin{array}{r}12 \\
10 \\
36 \\
7 \\
14 \\
2 \\
15 \\
11 \\
18\end{array}$ & $\begin{array}{r}8 \\
20 \\
22 \\
10 \\
14 \\
5 \\
20 \\
8 \\
13\end{array}$ & $\begin{array}{r}6 \\
9 \\
13 \\
8 \\
18 \\
3 \\
18 \\
4 \\
24\end{array}$ & $\begin{array}{r}14 \\
13 \\
8 \\
13 \\
5 \\
25 \\
14 \\
23\end{array}$ & $\begin{array}{c}-\overline{8} \\
7 \\
8 \\
\text { Fast } \\
8 \\
43 \\
6 \\
24\end{array}$ & \begin{tabular}{|}
8 \\
14 \\
8 \\
8 \\
ended \\
10 \\
18 \\
14 \\
\end{tabular} & $\begin{array}{r}5 \\
12 \\
11 \\
7 \\
2 \\
17 \\
14\end{array}$ & $\begin{array}{r}9 \\
10 \\
12 \\
5 \\
9 \\
19 \\
14\end{array}$ & $\begin{array}{r}6 \\
9 \\
19 \\
4 \\
10 \\
16 \\
7 \\
12\end{array}$ & $\begin{array}{r}9 \\
13 \\
15 \\
4 \\
21 \\
20 \\
6 \\
9\end{array}$ & $\begin{array}{r}7 \\
10 \\
23 \\
4 \\
20 \\
19 \\
12 \\
10\end{array}$ & $\begin{array}{r}9 \\
7 \\
19 \\
5 \\
17 \\
22 \\
8 \\
14\end{array}$ & $\begin{array}{r}14 \\
9 \\
23 \\
8 \\
18 \\
11 \\
7 \\
14\end{array}$ \\
\hline
\end{tabular}

24-hour periods, and an aliquot is analysed for its content of sodium and potassium by standard flame photometer techniques by the same observer (J.R.).

\section{Results}

In Fig. 1 the age and sex distribution of the patients studied is shown. The urinary excretion of sodium and potassium, respectively, between the 1st and 20th days and between the $40: \mathrm{h}$ and 60:h days of fasting is shown in Tables I-IV. This is given for 10 patients, two drawn from each of the first five groups in Fig. 1. These periods have been arbitrarily chosen to show the early and late responses in these functions in a significant number of patients.

From the tables a uniform pattern of potassium excretion can be discerned. In the first week of fasting there is an increase, above prefasting levels, in potassium excretion. Thereafter it falls and is maintained at a reduced level-in the range 10 to $20 \mathrm{mEq} /$ day-throughout. With increasing length of fast there is a tendency for potassium excretion to fall further (Fig. 2).

The pattern of urinary sodium excretion is more complex. The most frequent response is that of rapid reduction in urinary sodium excretion and maintenance of this muchreduced level throughout fasting. This is similar to urinary potassium excretion except that greater conservation of sodium is achieved. The response is stable and teleologically

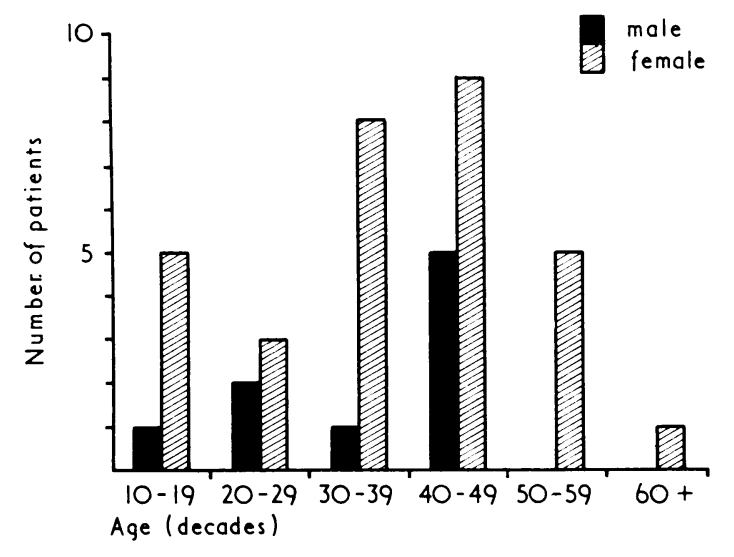

FIG. 1-Age and sex distribution of 40 obese, fasting patients. appropriate. It occurred in 25 of the patients in this series. An example of this response is shown in Fig. 3.

In 12 subjects, all females, a different response was seen. It consisted of a pattern of great fluctuation in sodium excretion with daily outputs ranging between 30 and $100 \mathrm{mEq}$. In some there was continuous fluctuation in sodium excretion, in some there was a cycle of almost regularly recurring peaks of excretion, and in others there was a grossly irregular, seemingly random excretion of sodium. An example of this response is shown in Fig. 4.

In three patients (two males and a female) a third response was seen which appeared to combine features of the first two responses. After a variable but prolonged ( $>30$ days) period of sodium conservation they went on to show a fluctuating sodium loss. This was associated with the loss of the previously established pattern of regular, progressive weight loss (Fig. 5).

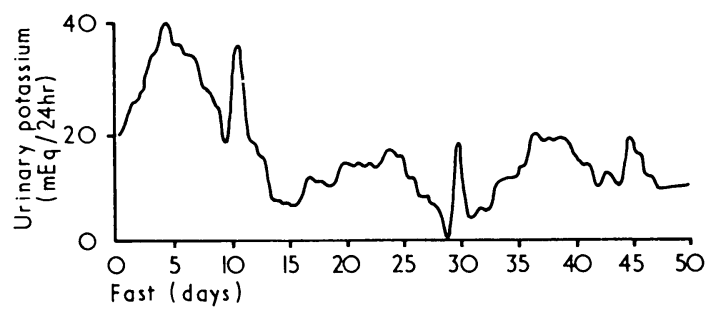

FIG. 2-Typical urinary potassium excretion in fasting (non-oscillatory).

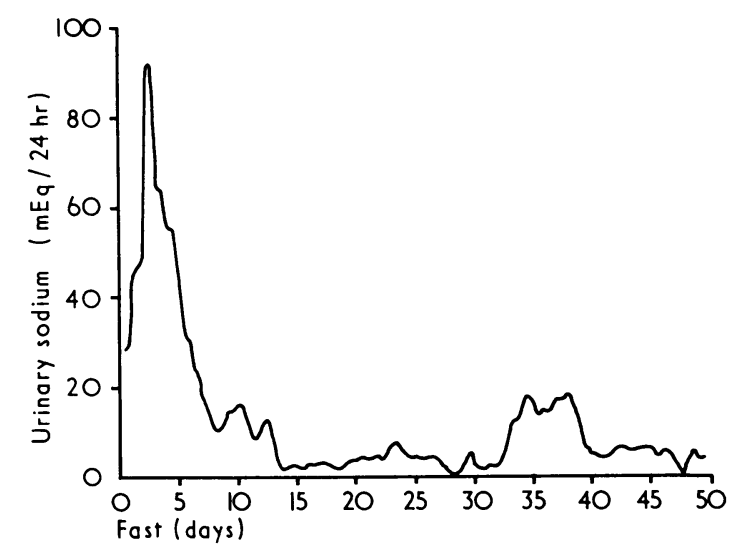

FIG. 3-Stable urinary sodium excretion in fasting (nonoscillatory). 


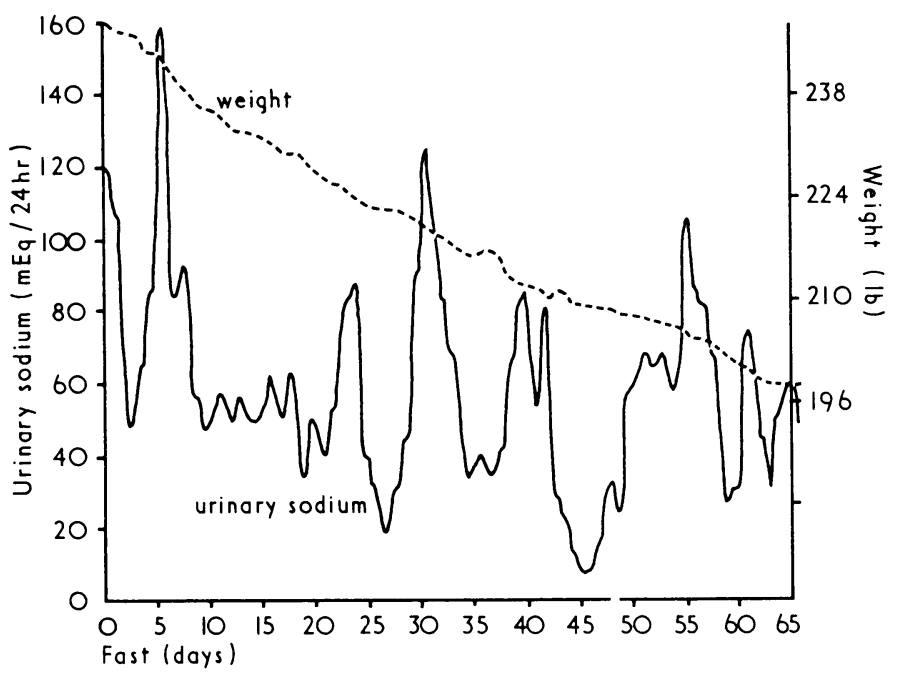

FIg. 4-Progressive weight loss and oscillatory urinary sodium excretion.

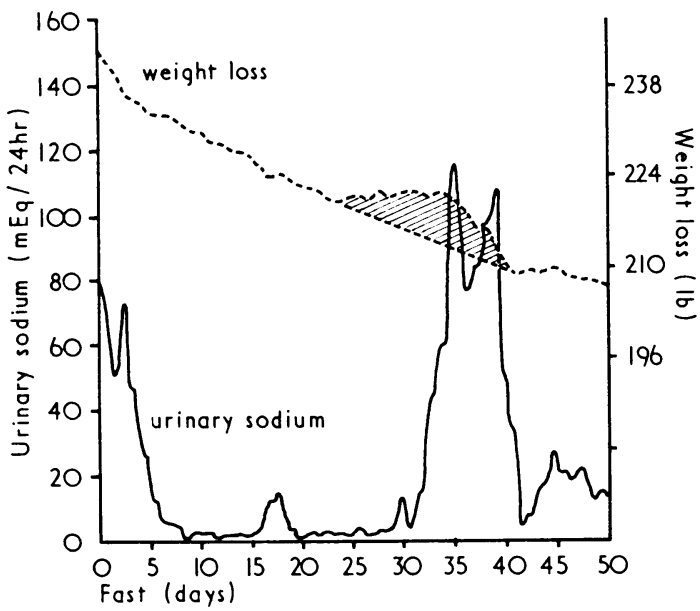

FIG. 5-Urinary sodium excretion in fasting-transitional response-related to irregular weight loss (shaded area).

\section{Discussion}

Daily weight loss in fasting obese subjects averages 0.2 to 0.4 $\mathrm{kg}$. Based on the estimate of a potassium content of intracellular fluid of $151 \mathrm{mEq} / 1$. (Gamble, 1954), and accepting a lower value for adipose tissue, it is clear that urinary potassium excretion in fasting subjects can be derived from the breakdown of fatty tissue and does not involve a charge on potassium balance. This is further supported by urinary potassium excretion studies on refeeding. The standard response is that of an immediate reduction in urinary potassium which lasts for a few days only and thereafter rises rapidly to normal levels. If a significant potassium deficit had been incurred during fasting the appropriate renal response would be a period of conservation directly related to the size of the deficit incurred. The increased potassium excretion in the first week of fasting has been shown to be due to increased gluconeogenesis from excessive utilization of lean body mass and is associated with a raised urinary nitrogen loss (Felig et al., 1969).

Sodium homoeostasis in fasting obese subjects is a more complex response. This is to be expected since a multiplicity of hormones and factors, both renal and extrarenal, are known to affect urinary sodium excretion. The relationship between sodium balance and blood pressure is a further complex variable influencing this situation. The investigation of a dynamic control system of this complexity presents great problems. A possible approach is suggested below.
The role of the kidney as the regulator of the internal vironment has been incontrovertibly established for ove century. In fasting subjects, after the cessation of bowel $\mathrm{e}$ uation, the kidneys become the sole, major excretory orga: the body-that is, the urinary output of such patients refl the metabolic changes necessary to maintain homoeostasi further consequence of the biological importance of sodius that its loss or elimination from the system-in fasting jects the urinary output-is a highly controlled response.

To analyse these responses (Figs. 3 and 4 ) it is logica turn to control system theory to attempt to explain then can be shown mathematically that in any system in w there is feedback control of function the probability of : systems, in certain conditions showing oscillatory behavi approaches unity with increasing complexity of cor (T. Wheldon, personal communication, 1970). This respi is typical of many biological systems, and the likelihoor oscillatory behaviour occurring there was deduced Morowitz (1966). This has led to the increasing recognitio the response in biological systems, in particular in the re ery of red cells after marrow irradiation (Kirk et al., 1 Orr et al., 1968). In physiological or steady-state condit oscillatory response is a latent property. Under stress response of the system alters, and it is in this phasi altered activity that oscillatory behaviour may manifest its

Urinary sodium excretion in fasting is a further exampl oscillatory behaviour response in biological systems. It $r$ be stressed that the common response is not oscillatory, and when peaks of excretion occur these appear to be rar damped out. In 12 patients the response is oscillatory of , able complexity. The possibility of this response $b$ artefactual, induced by surreptitious eating, is considere be dismissed. Such patients are ketotic throughout fas indicating continuous metabolism of adipose tissue. $\Lambda$ importantly, this fluctuating sodium loss is associated regular progressive weight loss rather than the irregular tern of weight loss induced by surreptitious eating (Fig. 4 is clear that these oscillations are generated by metal requirements not related to fasting. In some patients $t$ beats appear to be triggered by an expansion in extracel volume, as evidenced by irregular weight loss and/or c fluid retention, suggesting the action of a threshold con ling effect (Fig. 5).

The problem of the origin of the urinary sodium rem It cannot be derived from the breakdown of adipose ti and becomes a charge on sodium balance. It can arise from an existing body pool or reserve such as that in bor by a reduction in extracellular fluid. Another possibili1 that the fall in blood pressure, which occurs in all fa subjects (Runcie and Thomson, 1970), in some unknown releases sodium.

The analysis of the urinary sodium excretory respons fasting is clearly of importance. The complexity is such this can probably be approached only by deriving a m: matical model of the integrated behaviour of the whole tem and using this to explore and define the inter tionships of the numerous functions which control sor excretion.

I wish to thank Professor S. Alstead and Professor A. Golk for permission to study patients under their care, Mr. T. Whi for much helpful discussion and mathematical guidance, and $P$. Waldie and the department of medical photography and graI Stobhill Hospital, for preparing the illustrations.

\section{References}

Bloom, W. L. (1959). Metabolism, 8, 214

Cahill, G. F., jun., et al. (1966). Fournal of Clinical Investigation, 45, Drenick, E. J., Swendseid, M. E., Blahd, W. H., and Tuttle, S. G. ( fournal of the American Medical Association, 187, 100.

Duncan, G. G., Frazer, R. I., and Cristofori, F. C. (1962). Fournal American Medical Association, 181, 309. 
Felig, P., Owen, O. E., Wahren, J., and Cahill, G. F., jun. (1969). fournal of Clinical Investigation, 48, 584

Gamble, J. L. (1954). Chemical Anatomy, Physiology and Pathology of Extracellular Fluid, 6th Edn. Cambridge, Massachusetts, Harvard Extracellular Fluid,

Kirk, J., Orr, J. S., and Hope, C. S. (1968). British fournal of Haematology, $15,35$.
Morowitz, H. J. (1966). Fournal of Theoretical Biology, 13, 60.

Orr, J. S., Kirk, J., Gray, K. G., and Anderson, J. R. (1968). British fournal

Owen, O. E., Felig, P., Morgan, A. P., Wahren, J., and Cahill, G. F., jun. (1969). Fournal of Clinical Investigation, 48, 574.

Runcie, J., and Thomson, T. J. (1970). British Medical fournal, 3, 432.

Thomson, T. J., Runcie, J., and Miller, V. (1966). Lancet, 2, 992.

\title{
Controlled Trial of Metoclopramide in the Treatment of Flatulent Dyspepsia
}

\author{
A. G. JOHNSON
}

British Medical fournal, 1971, 2, 25-26

\section{Summary}

A double-blind cross-over trial of metoclopramide (Maxolon) against placebo was undertaken in 42 patients with flatulent dyspepsia. A highly significant difference was found in favour of the active drug $(P<0.01)$. The time at which the drug is given in relation to the meal and onset of symptoms is probably important. It is concluded that metoclopramide is effective in the short-term treatment of these symptoms but should be started only after thorough investigations have excluded more serious disease.

\section{Introduction}

Flatulent dyspepsia is a well-known symptom complex occurring in association with cholelithiasis when it may persist after cholecystectomy (Maingot, 1956; Bodvall, 1964), but it has been found with equal frequency in patients with a normal cholecystogram (Price, 1963). It has been defined by Rhind and Watson (1968) as follows: "Epigastric discomfort after meals, a feeling of fullness so that tight clothing is loosened, eructation with temporary relief, and regurgitation of sour fluid to the mouth with heartburn." The cause of these symptoms is not known but they are possibly associated with abnormal gastrointestinal motility, leading to regurgitation of duodenal juice into the stomach (Capper et al., 1967) and delayed gastric emptying.

Metoclopramide increases the strength of gastric antral contractions and speeds gastric emptying, when measured radiologically (Kreel, 1970) or by a dye dilution method (Connell and George, 1969); this effect is still observed after vagotomy (Banke, 1968). It appears to relax the duodenal cap (Jacoby and Brodie, 1967) and cause duodenal contractions to follow those of the antrum if they were previously out of phase (Johnson, 1971), and would, therefore, tend to prevent pyloric regurgitation. It acts by enhancing the local effect of acetylcholine on the gastric smooth muscle (Eisner, 1968), and it also has a central antiemetic effect. It would seem, on theoretical grounds, a suitable drug with which to treat flatulent dyspepsia and has been found to be effective in practice in France and in two preliminary trials in Britain (Boisson and Albot, 1966; Trafford et al., 1967; Marshall, 1970). Charing Cross Hospital Medical School, Fulham Hospital, London
W6 8RF

A. G. JOHNSON, F.R.c.s., Lecturer in Surgery

\section{Patients and Methods}

Selection of Patients.-Consecutive patients attending a gastroenterological clinic were admitted to the trial if they complained only of flatulent dyspepsia as defined above. They came from three clinical groups: (1) Those with radiograph negative dyspepsia (normal barium meal and cholecystogram), but including some patients with a small hiatus hernia; (2) Those with persistent flatulent dyspepsia after cholecystectomy; and (3) Those with these symptoms after vagotomy and pyloroplasty or pyloroplasty alone.

Plan of Trial.-A double-blind cross-over trial was devised of metoclopramide against placebo, each patient being used as his own control. Metoclopramide was given as $10-\mathrm{mg}$ tablets three times a day, the placebo and active tablets being given for two weeks each. This comparatively short period was chosen to avoid the natural fluctuation of the symptoms that tends to occur over the months. If patients were already on treatment for the symptoms with drugs other than antacids a week without drugs was allowed before the trial began. Because metoclopramide probably has a fairly short duration of action it was given just before the meal to patients whose symptoms occurred during or soon after the meal (up to 45 minutes), and after the meal to those whose symptoms occurred one hour or more after food. The patient was supplied with separate containers for each of the four weeks.

Method of Assessment.-The flatulent dyspepsia syndrome was divided into nine individual symptoms: belching; full feeling after normal meals; inability to finish meals; abdomen becomes distended, clothes have to be loosened; burning discomfort in epigastrium; burning discomfort in chest (heartburn); bitter fluid in mouth; nausea; and vomiting. The patients were seen before the trial, and each symptom was recorded as absent, mild, or severe. They were asked to note how these symptoms changed each week. They were told that two types of tablet, which looked identical, were being tried to see which was better. At the end of four weeks they were interviewed again and the degree of symptoms during each week was recorded. Finally, they were asked which two weeks were better. Most stated without hesitation that either the first two or the second two weeks were better, but some said that all the weeks were equally good and some that none of the tablets made any difference. Others stated that either the first and fourth or second and third weeks were better, clearly showing no difference between active drug and placebo. A more complicated arbitrary scoring system involving the types of food eaten was abandoned as it was thought to introduce more observer bias. At least once during each week of the trial the patients were told to try some food known to produce symptoms. 